\title{
Where should the damage control surgery be performed, at the nearest health center or at a fully equipped hospital?
}

\author{
Mustafa Uğur, M.D.,', Seçkin Akküçük, M.D.,' ${ }^{1}$ Yavuz Savaş Koca, M.D., ${ }^{2}$ Cem Oruç, M.D.,' \\ Akın Aydoğan, M.D., ${ }^{1}$ Erol Kılıç, M.D., ${ }^{1}$ İbrahim Yetim, M.D., ${ }^{1}$ Muhyittin Temiz, M.D. ${ }^{1}$ \\ ${ }^{1}$ Department of General Surgery, Mustafa Kemal University Faculty of Medicine, Hatay-Turkey \\ ${ }^{2}$ Department of General Surgery, Süleyman Demirel University Faculty of Medicine, Isparta-Turkey
}

\begin{abstract}
BACKGROUND: Transport of casualties from a combat area to a fully equipped hospital where all techniques of damage control surgery (DCS) can be performed requires a great deal of time. Therefore, prior to transport, prompt control of hemorrhage and contamination should be achieved, and resuscitative procedures should be performed at the nearest health center. The aim of the present study was to investigate the effect of the location at which DCS was performed on rates of mortality.

METHODS: The present retrospective study included $5 \mathrm{I}$ combat casualties who underwent DCS at the present clinic or at hospitals nearest the combat area due to high kinetic energy gunshot injuries to the abdomen between 2010 and 20I5. Patients were evaluated in terms of acidosis, hypothermia, coagulopathy, and mortality.

RESULTS: Patients were divided into 2 groups depending on the location where the first step of DCS was performed: (I) at the present hospital or (2) at other hospitals. Group I comprised 26 patients (5I\%), and Group 2 comprised 25 (49\%). Total mortality occurred in 23 (45. I\%) patients, including 15 (57.7\%) patients in Group I and 8 (32\%) in Group 2. In Group I, mean time from injury to hospital admission was longer, and deep acidosis, hypothermia, and coagulopathy were more marked.
\end{abstract}

CONCLUSION: Initial surgical control of hemorrhage and contamination in patients injured by high kinetic gunshots should be promptly achieved at the nearest health center. In this way, acidosis, hypothermia, and coagulopathy can be prevented, and the risk of mortality can be reduced.

Keywords: Damage control surgery; locality of surgery; mortality.

\section{INTRODUCTION}

Damage control surgery (DCS) has been used as a life-saving procedure in patients with severe trauma since its first description in 1983. The primary aim in the performance of DCS is to increase likelihood of patient survival by maintaining tolerable levels of the lethal triad of acidosis, hypothermia, and coagulopathy. ${ }^{[1]}$

Complete performance of DCS requires experienced staff and fully equipped hospitals that can provide technical equip-

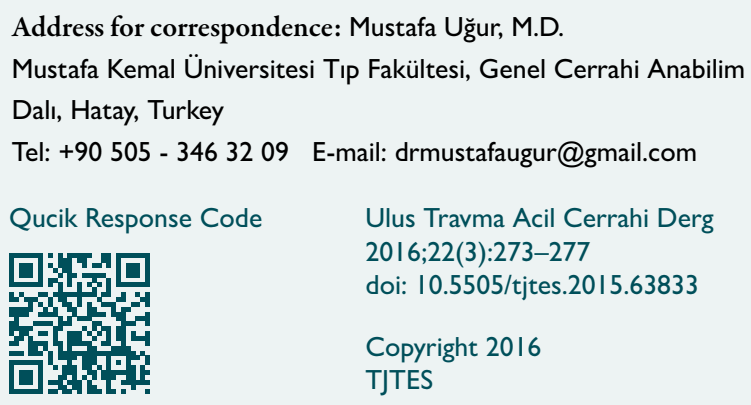

ment needed in order to reverse acidosis, hypothermia, and coagulopathy. ${ }^{[2]}$ However, as combat and riots are irregular in war zones, experienced staff and fully equipped hospitals are difficult to find. ${ }^{[3]}$ Therefore, combat casualties are transported either long distances to fully equipped hospitals or a short distance to the nearest hospital, where the first step of DCS is performed.

The aim of the present study was to investigate the effect of DCS administration location on the mortality rate of combat casualties due to high kinetic energy gunshot injuries to the abdomen. DCS was either performed in entirety at the Mustafa Kemal University Medical School General Surgery Department or the first step was performed at hospitals close to the combat area before the patients were transported, between 2010 and 2015 .

\section{MATERIALS AND METHODS}

The present retrospective study included $5 \mathrm{I}$ combat casualties. All casualties were transported to the Turkish border, either by vehicle or by unidentified method, before being 
transported to the clinic by ambulance. Patients were divided into 2 groups depending on the location at which the first step of DCS was performed: (I) at the present hospital or (2) at other hospitals. Age, gender, time from injury to hospital admission, body temperature at hospital admission, $\mathrm{pH}$ level, systolic blood pressure, international normalized ratio (INR) level, associated organ injury, amount of blood transfused, and mortality were recorded. Other information included exact time of injury, admission time to other hospital, laboratory parameters, amount of erythrocyte suspension transfused, and body temperature, obtained via clinical records sent from Syrian hospitals, accompanying ambulance personnel, or immediate accounts of escorts. Following admission, physical examination was performed, and both groups underwent the same resuscitation procedure. Axillary body temperature was measured, and blood samples were obtained for whole blood count, arterial blood gas, and biochemical and coagulation tests. Following initial evaluation, the patients were transferred either directly to the operating room or to the intensive care unit (ICU). Four patients whose preoperative cardiopulmonary resuscitation took more than 5 minutes were excluded, as were 3 patients who died during DCS procedure performed at the present hospital, 2 of whom presented with aortic injury, and I of whom presented with inferior vena cava injury. Also excluded were 5 patients with incomplete preoperative data.

\section{Damage Control Surgery}

Each initial examination was performed in the emergency service unit. Patients who had not undergone surgery in Syria were promptly transferred to the operating room. Following the infusion of 2000-cc lactated Ringer's solution, systolic blood pressure was considered (I) as stable in patients with systolic blood pressure $>90 \mathrm{mmHg},(2)$ as temporarily stable in patients with $>90 \mathrm{mmHg}$ that lowered to $<90 \mathrm{mmHg}$ as a result of cessation of infusion, requiring transfusion of blood and blood products, and (3) as unstable in patients with systolic blood pressure $<90 \mathrm{mmHg}$. Decision to perform DCS was based on following sings: pre- or intraoperative arterial $\mathrm{pH}<7.20$, body temperature $<35.5^{\circ} \mathrm{C}$, INR level $>1.9$, and presence of hemodynamic instability.

Patients were evaluated by an infectious diseases specialist, and antibiotic therapy was initiated. Central venous catheter was inserted for fluid and electrolyte replacement. In patients who underwent the first step of DCS in Syria, central venous catheter was inserted in the ICU. Warmed blankets and heaters were used to prevent temperature loss in patients. In addition, fluids were heated to body temperature before transfusion.

In Group I, laparotomy was performed via midline incision. Initial step included hemostatic control via abdominal packing in all 4 abdominal quadrants. Vascular injuries were treated using vascular clamp or suture ligation. Diaphragmatic inju- ries were primarily repaired and tube thoracostomy was performed in injuries preoperatively diagnosed. Selective ligation of hepatic and biliary leakages was achieved using finger fracture technique or packing procedure. Finger fracture technique was performed following the Pringle maneuver, which was performed with an overall median time of 20 min. Packing procedure was performed with the insertion of 2-4 packs around the liver. Splenectomy was performed for splenic injuries. For major intestinal injuries, primary closure was performed with intestinal staplers or 2-0 silk suture. No intestinal resection was performed, and no anastomosis, feeding tubes, or ostomy were used.

In order to avoid acute abdominal compartment syndrome, and to achieve rapid transfer of the patient to ICU, the skin was simply closed with skin-only closure or sterile serum physiologic bag (Bogota bag). Following DCS procedure, all patients were transferred to the ICU, and fluid resuscitation was performed, with intravenous fluid, blood, plasma, and volume expanders. Following correction of physiological and biochemical abnormalities, definitive surgery was performed 24-48 $\mathrm{h}$ after initial surgery.

Associated organ injuries were treated during definitive surgery. Intestinal injuries were treated using primary repair, ileostomy-colostomy, or anastomotic techniques.

\section{Statistical Analysis}

Data were analyzed using SPSS software for Windows (version 20.0; SPSS Inc., Chicago, IL, USA). Student's t-test was used to analyze demographic data. Two-way analysis of variance for repeated measures was used to analyze changes over time. Mann-Whitney $U$ test and $\chi^{2}$ test were used with appropriate corrections to analyze ordinal data. Continuous variables were presented as mean $\pm S D$ or median (range). A p value of $<0.05$ was considered significant.

\section{RESULTS}

Patients were divided into 2 groups depending on the location where the first step of DCS was performed: (I) at the present hospital or (2) at other hospitals. Group I included 26 (5I\%) patients, and Group 2 included 25 (49\%). All 5 I patients were male (100\%), with a mean age of $27.92 \pm 8.51$ years in Group I and 34.84 12.10 years in Group 2. No significant difference in mean age was found $(p=0.02)$. Mean time from injury to hospital admission was $188.07 \pm 52$ minutes in Group I and 85.20 29.59 minutes in Group 2, and a significant difference was observed $(p=0.001)$. Mean $\mathrm{pH}$ level was 7.14 \pm 0.13 in Group I and 7.24 \pm 0.08 in Group 2, and a significant difference was found $(p=0.002)$. Mean body temperature was $35.89 \pm 0.50^{\circ} \mathrm{C}$ in Group $\mathrm{I}$ and $36.08 \pm 0.65^{\circ} \mathrm{C}$ in Group $2(p=0.234)$. Mean INR level was $1.95 \pm 0.64$ in Group $I$ and $1.86 \pm 0.45$ in Group $2(p=0.602)$. No significant difference was observed between the groups regarding amount of 
Table I. Clinical profiles of the patients at admission

\begin{tabular}{|c|c|c|c|}
\hline Parameter & Group I $(n=26 ; 51 \%)$ & Group II $(n=25 ; 49 \%)$ & $\mathbf{p}$ \\
\hline Age & $27.92 \pm 8.51$ & $34.84 \pm 12.10$ & $=0.02$ \\
\hline Gender & Male (100\%) & Male ( $100 \%)$ & \\
\hline \multicolumn{4}{|l|}{ Mechanism of Injury } \\
\hline Gunshot & $n=17 ; 54.8 \%$ & $n=14 ; 45.2 \%$ & $=0.493$ \\
\hline Shrapnel & $n=9 ; 45.0 \%$ & $n=I I ; 55.0 \%$ & \\
\hline Time from injury to hospital admission (min) & $188.07 \pm 52.00$ & $85.20 \pm 29.59$ & $=0.001$ \\
\hline $\mathrm{pH}$ & $7.14 \pm 0.13$ & $7.24 \pm 0.08$ & $=0.002$ \\
\hline Body temperature $\left({ }^{\circ} \mathrm{C}\right)$ & $35.89 \pm 0.50$ & $36.08 \pm 0.65$ & $=0.234$ \\
\hline INR & $1.95 \pm 0.64$ & $1.86 \pm 0.45$ & $=0.602$ \\
\hline ES & $3.61 \pm 1.57$ & $3.72 \pm 1.62$ & $=0.816$ \\
\hline \multicolumn{4}{|l|}{ Systolic blood pressure } \\
\hline Stable & $\mathrm{n}=3 ; 11.5 \%$ & $n=8 ; 32.0 \%$ & $=0.68$ \\
\hline Temporarily stable & $n=15 ; 57.6 \%$ & $n=7 ; 28.0 \%$ & \\
\hline Unstable & $n=8 ; 30.7 \%$ & $n=10 ; 40.0 \%$ & \\
\hline \multicolumn{4}{|l|}{ Associated organ injury } \\
\hline Liver & $n=5 ; 19.2 \%$ & $n=6 ; 24.0 \%$ & $=0.918$ \\
\hline Liver and other abdominal organs & $\mathrm{n}=\mathrm{I} \mid ; 42.3 \%$ & $n=10 ; 40.0 \%$ & \\
\hline Abdominal organs other than liver & $n=10 ; 38.4 \%$ & $n=9 ; 36.0 \%$ & \\
\hline Mortality & $n=15 ; 57.7 \%$ & $n=8 ; 32.0 \%$ & $=0.65$ \\
\hline
\end{tabular}

Group I: The patients who underwent damage control surgery at our hospital; Group II: The patients who underwent the first steps of damage control surgery at other hospitals; ES: Erythrocyte suspension transfused; $p<0.05$.

erythrocyte transfusion, hemodynamic stability, mechanism of injury, or associated organ injury. Total mortality occurred in $23(45.1 \%)$ patients, including $15(57.7 \%)$ patients in Group I and 8 (32.0\%) patients in Group 2. No significant difference regarding total mortality was found $(p=0.65)$ (Table I).

\section{DISCUSSION}

DCS consists of 3 steps when used to treat patients with hypothermic, coagulopathic, and acidotic abdominal trauma. The first and most important step includes prompt surgical control of hemorrhage and contamination. ${ }^{[4,5]}$ Decision to perform DCS should be made in the first 15 minutes and be based on indications including hypothermia (body temperature $<35.5^{\circ} \mathrm{C}$ ), severe acidosis (arterial $\mathrm{pH}<7.20$ ), and coagulation disorder (INR > 1.9). ${ }^{[6,7]}$ However, the decision should be made before the onset of all 3 indications, which may mark the "point of no return" and may indicate DCS failure. Systolic blood pressure can be used as an indication of hemodynamic instability. ${ }^{[8]}$

The second step of DCS includes core rewarming and completion of acute resuscitation. The primary goal of this step is to reverse hypothermia, acidosis, and coagulopathy. ${ }^{[9,10]}$ In major trauma patients with acidosis, hypothermia, and hypotension, the presence of coagulopathy is characterized by
INR $>1.9$ and/or activated partial thromboplastin time level $>60$ seconds. In such patients, administration of fresh frozen plasma and cryoprecipitate, in addition to transfusion of crystalloid fluids and erythrocyte suspension, has been reported to decrease risk of mortality. ${ }^{[1-13]}$ For the reversal of hyperthermia, core rewarming should be performed in the operating room and the $\mathrm{ICU}$, and the blood and the intravenous fluids should be rewarmed. The third step of DCS includes definitive surgery for all associated organ injuries following metabolic normalization. ${ }^{[14-16]}$

Performance of all 3 steps of DCS requires an ICU supplied with technical equipment, available blood stock, mechanical ventilator, advanced monitorization systems, and trained medical personnel. Decision to perform DCS may be controversial in war zones, and can also be controversial during hospital admission, depending on the availability of equipment required for DCS performance. In addition, the decision can be dependent on other factors, including the number and frequency of admitted combat casualties, the number of casualties anticipated, the availability and qualifications of medical personnel, and the availability of blood supply. ${ }^{[17]}$

In times of war, unexpected scenarios may occur regarding treatment and evacuation of combat casualties. Accounts of 
casualties and their clinical and surgical features indicate that combatants in the Syrian civil war have established health centers near the combat area where laparotomy can be performed. It has also been revealed that initial triage for combat casualties is performed at these centers, where the decision regarding whether surgery should be performed in Syria or Turkey is made. Patients transported from these centers include those who have undergone surgery in Syria before being transported to Turkey for ICU support, as well as those who have been directly transported to Turkey for surgery.

Health facilities in combat areas are generally inoperative or inadequate. ${ }^{[17]}$ Given the clinical and surgical features of patients who underwent the first step of DCS in Syria and were then transported (Group 2), it is presently believed that the health centers at which those procedures were performed have equipment and personnel adequate for the performance of the first step of DCS. However, clinical records reveal that the hospitals have inadequate ICUs.

Prolonged administration time also leads to delayed DCS and resuscitation. Hence, poor prognosis in the management of patients with penetrating abdominal trauma is caused by the lethal triad. ${ }^{[7]}$ In patients who underwent DCS at the present hospital, deep acidosis, hypothermia, and coagulopathy were more noticeable. It is presently believed that this was associated with the higher mortality rate in this group. It is also believed that more noticeable presence of the lethal triad in this group resulted from prolonged mean time from injury to hospital admission. On the other hand, the most important problem for the patients who underwent the I $^{\text {st }}$ step of DCS in Syria was the delay in administration of the $2^{\text {nd }}$ step, which includes the prompt reversal of acidosis, hypothermia, and coagulopathy.

In combat casualties who require DCS due to severe abdominal trauma, the $\left.\right|^{\text {st }}$ step should be performed at the health center nearest the combat area, after which the transport of the patient for the administration of the $2^{\text {nd }}$ and $3^{\text {rd }}$ steps may prevent occurrence of the lethal triad, and may decrease risk of mortality. Vehicles used for patient transport should be supplied with equipment required to reverse hypothermia, acidosis, and coagulopathy. The employment of trained medical personnel may also contribute to the successful treatment of combat casualties.

Conflict of interest: None declared.

\section{REFERENCES}

1. Stagnitti F. Uncontrolled bleeding in patients with major abdominal trauma. Ann Ital Chir 2013;84:365.

2. Eiseman B, Moore EE, Meldrum DR, Raeburn C. Feasibility of damage control surgery in the management of military combat casualties. Arch Surg 2000;135:1323-7. Crossref

3. Giannou C, Baldan M. First aid in armed conflict. In: Giannou C, BaldanM, eds. War surgery: working with limited resources in armed conflict and other situations of violence. Vol. 1. Geneva: International Committee of the Red Cross 2010:153-61.

4. Nicol AJ, Hommes M, Primrose R, Navsaria PH, Krige JE. Packing for control of hemorrhage in major liver trauma. World J Surg 2007;31:56974. Crossref

5. Aydin U, Yazici P, Zeytunlu M, Coker A. Is it more dangerous to perform inadequate packing? World J Emerg Surg 2008;3:1. Crossref

6. Kouraklis G, Spirakos S, Glinavou A. Damage control surgery: an alternative approach for the management of critically injured patients. Surg Today 2002;32:195-202. Crossref

7. Rotondo MF, Zonies DH. The damage control sequence and underlying logic. Surg Clin North Am. 1997;77:761-77. Crossref

8. Matsumoto H, Mashiko K, Sakamoto Y, Kutsukata N, Hara Y, Yokota H. A new look at criteria for damage control surgery. J Nippon Med Sch 2010;77:13-20. Crossref

9. Hoey BA, Schwab CW. Damage control surgery. Scand J Surg 2002;91:92-103.

10. Rotondo MF, Schwab CW, McGonigal MD, Phillips GR 3rd, Fruchterman TM, Kauder DR, et al. 'Damage control': an approach for improved survival in exsanguinating penetrating abdominal injury.J Trauma 1993;35:375-83. Crossref

11. Borgman MA, Spinella PC, Perkins JG, Grathwohl KW, Repine T, Beekley $\mathrm{AC}$, et al. The ratio of blood products transfused affects mortality in patients receiving massive transfusions at a combat support hospital. J Trauma 2007;63:805-13. Crossref

12. Byers R. An upshot of war - damage control resuscitation. Int Emerg Nurs 2010;18:221-5. Crossref

13. Sirieix D, Delayance S, Paris M, Massonnet-Castel S, Carpentier A, Baron JF. Tris-hydroxymethyl aminomethane and sodium bicarbonate to buffer metabolic acidosis in an isolated heart model. Am J Respir Crit Care Med 1997;155:957-63. Crossref

14. Kapan M, Onder A, Oguz A, Taskesen F, Aliosmanoglu I, Gul M, et al. The effective risk factors on mortality in patients undergoing damage control surgery. Eur Rev Med Pharmacol Sci 2013;17:1681-7.

15. Moore EE, Cogbill TH, Malangoni MA, Jurkovich GJ, Shackford SR, Champion HR, et al. Organ injury scaling. Surg Clin North Am 1995;75:293-303. Crossref

16. Sharp KW, Locicero RJ. Abdominal packing for surgically uncontrollable hemorrhage. Ann Surg 1992;215:467-75. Crossref

17. Giannou C, Baldan M, Molde Å. Injuries to the abdomen. In: Giannou C, BaldanM, Molde $\AA$ eds. War surgery: working with limited resources in armed conflict and other situations of violence. Vol. 2. Geneva: International Committee of the Red Cross 2013:442-5. 
ORİJINAL ÇALIŞMA - ÖZET

\section{Hasar kontrol cerrahisi nerede yapılmalı? Yapılabilecek en yakın yerde mi, tam donanımlı hastanede mi? \\ Dr. Mustafa Uğur, ${ }^{1}$ Dr. Seckin Akküçük, ${ }^{1}$ Dr. Yavuz Savaş Koca, ${ }^{2}$ Dr. Cem Oruç, ${ }^{1}$ Dr. Akın Aydoğan, ${ }^{1}$ \\ Dr. Erol Kılıç, ${ }^{1}$ Dr. İbrahim Yetim, ${ }^{1}$ Muhyittin Temiz ${ }^{1}$}

${ }^{1}$ Mustafa Kemal Üniversitesi Tıp Fakültesi, Genel Cerrahi Anabilim Dalı, Hatay

${ }^{2}$ Süleyman Demirel Üniversitesi Tıp Fakültesi, Genel Cerrahi Anabilim Dalı- Isparta

AMAÇ: Savaş koşullarında ciddi şekilde yaralanmış hastaları hasar kontrol cerrahisinin tüm aşamalarını başarıyla yapabilecek tam donanımlı hastanelere nakletmek için uzun süreye ihtiyaç vardır. Bu nedenle savaşta yaralananlar ya yaralanma alanına yakın birimlerde kanama ve kontaminasyon kontrolü sağlanarak yada sadece resusitatif işlemler yapılarak tam donanımlı hastanelere sevk edilmektedir. Bu çalışmanın amacı hasar kontrol cerrahisinin yapıldığı yer ile mortalite arasındaki ilişkiyi belirlemektir.

GEREÇ VE YÖNTEM: Bu çalışmaya 20I0-20I5 yılları arasında abdominal bölgeden yüksek kinetik enerjili ateşli silahlarla yaralandıktan sonra hastanemizde ya da yaralanma yerine daha yakın diğer hastanelerde hasar kontrol cerrahisi yapılan 5 I hasta dahil edildi. Hastalar hasar kontrol cerrahisinin ilk aşamasını oldukları yere göre gruplandırılarak asidoz, hipotermi, koagülopati ve mortalilte açısından değerlendirildi.

BULGULAR: Illk ameliyatı hastanemizde olanların sayısı 26'idi (\%5I). Diğer hastanelerde ameliyat olanların sayısı 25'di (\%49). Tüm hastaların \%45. I’i $(n=23)$ kaybedildi. IIlk ameliyatı hastanemizde yapılanların \%57.7'si $(n=15)$; diğer hastanelerde yapılanların \%32.0'si $(n=8)$ kaybedildi. Hastanemizde ameliyat olanlarda başvuru zamanı daha uzundu. Asidoz, hipotermi ve koagülopati daha belirgindi.

TARTIŞMA: Abdominal bölgeden yüksek kinetik enerjili silahlarla yaralananlarda kanama ve kontaminasyonun erken kontrolü yapılabilecek en yakın yerde gerçekleştirilmelidir. Bu uygulama asidoz, hipotermi ve koagülopati gelişmesini önleyebilir ve böylece mortalite oranının düşürülmesinde etkili olabilir.

Anahtar sözcükler: Ameliyatın yapıldı̆̆ı yer; hasar kontrol cerrahisi; mortalite.

Ulus Travma Acil Cerrahi Derg 2016;22(3):273-277 doi: 10.5505/tjtes.2016.63833 